\title{
Selection of Wastewater Treatment Plant Site for Bahir Dar Town, Ethiopia Using Multi-Criteria Analysis on GIS platform
}

\author{
Abinet Addis \\ Department of Civil Engineering, Debre Markos University, Debre Markos, Ethiopia
}

\begin{abstract}
The siting of wastewater treatment plant is an extremely complex task mainly due to the fact that the identification and selection process involves many factors and strict regulations. For proper identification and selection of appropriate sites for wastewater treatment plants careful and systematic procedures need to be adopted and followed. The main objective of this research was to find the environmentally and economically suitable location of wastewater treatment plant by using the GIS-based MCA approaches in Bahir Dar town. The present study had integrated road networks, rivers/streams, lake, geology, soil, slope, elevation, wind direction, groundwater wells, groundwater table, rural settlements, urban settlements and land use/ land cover for selecting a suitable wastewater treatment plant site within the study area. The relative weights of the factor were estimated using AHP and criteria maps were developed by using GIS spatial operations. Weighted linear combination was used to integrate weight with the factor maps. The final integration of weighted factor map and constraint map produced an overall wastewater treatment plant suitability map. The wastewater treatment plant site suitability map was presented in four suitability index such as highly suitable, moderately suitable, low suitable and unsuitable. The result shows that around $6.08 \%$ area is highly suitable for wastewater treatment plant site, $1.83 \%$ is moderately suitable, $0.61 \%$ of study area has low suitability and $91.48 \%$ area is unsuitable for wastewater treatment plant site. Among the highly suitable areas, five sites were selected and revaluated in terms of road network, river/streams, lake, geology, soil, slope, elevation, wind direction, groundwater wells, groundwater table, rural settlements, urban settlements and land use/land cover to select the optimal suitable site. Finally, site 4 was proposed as the most preferred option for the construction of the wastewater treatment plant site with the minimum effects on economic, environment risk and public health.
\end{abstract}

Keywords: Bahir Dar, GIS, MCA, Site selection, Wastewater Treatment Plant

DOI: $10.7176 / \mathrm{CER} / 13-3-02$

Publication date:May $31^{\text {st }} 2021$

\section{Introduction}

Wastewater is a problem in developing countries due to the accelerated rate of increasing population. The sources of wastewater are domestic, industrial, agricultural and commercial [1]. Thus, potential suitable sites must be selected for wastewater treatment plant to minimize the contamination of surface and groundwater especially those used for drinking water. In the world especially in developing countries like Ethiopia almost $90 \%$ of wastewater remains untreated causing widespread water pollution [6] [4].

In Bair Dar town, there are problems of wastewater treatment plant sites. Nearly two-thirds of all households in Bahir Dar discharge wastewater into rivers. They also discharge wastewater into Lake Tana and Abbay (Blue Nile) river through pipes and open ditches. Such discharges pollute the environment and create offensive smell and aggravate the conditions for the spread of communicable diseases [5].

The selection of wastewater treatment plant site is an extremely difficult task to achieve, because for the selections of the appropriate sites, multiple criteria have to be considered and there is no universal formula [11]. The wastewater treatment plant site selection depends on environmental, economical and social factors and a systematic process should be developed and followed [8].

Geographical Information System is a powerful tool to solve the wastewater treatment plant site selection problem, because it provides efficient manipulation and presentation of the data [3]. It is the most reliable tool, as it is capable of storing, retrieving, and analyzing a large amount of data, as well as providing output visualization. Furthermore, wastewater treatment plant siting analysis using GIS allows greater time effectiveness. The purpose of this study is to identify a wastewater treatment plant site that integrates a multicriteria decision analysis method, which consists of the analytical hierarchy process (AHP) and weighted linear combination (WLC) methods, within a GIS environment in the case of Bahir Dar town.

\section{MATERIALS AND METHODS}

\subsection{Study Area}

Bahir Dar town is located in the Northwestern part of the country at a distance of approximately $565 \mathrm{kms}$ by road from Addis Ababa on the Gondar high way. The town is the center of the Amhara National Regional State and it is bounded to the north by Lake Tana and marks the sources of the great Blue Nile River. According from UTM coordinate system, the location of the town is approximately between $312000 \mathrm{~m}-334000 \mathrm{~m}$ East direction 
and $1273000 \mathrm{~m}-1289000 \mathrm{~m}$ North direction. The total area of the town is $213.41 \mathrm{~km}^{2}$.

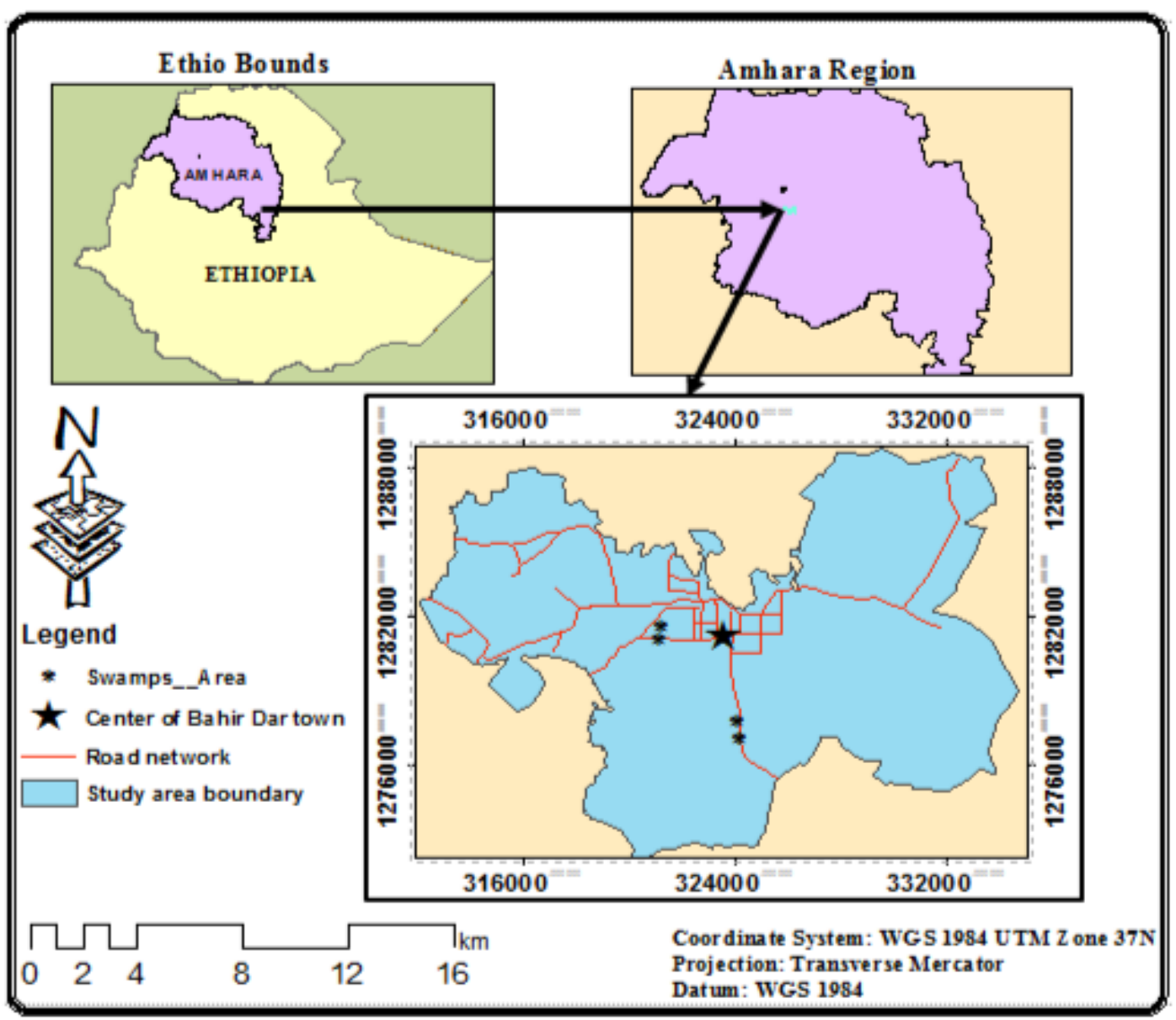

Fig 1: Location Map of the study area

\subsection{Data Type and Source of Data}

For this study different types of datasets were integrated within GIS environment to come up with final output of wastewater treatment plant site selection areas in Bahir Dar Town. The datasets used are tabulated below in (table 1).

Table 1: Summary of types of dataset, format and source of data

\begin{tabular}{|l|l|l|l|}
\hline No. & Types of Datasets & Format & Sources \\
\hline 1 & Land use land cover & Raster & $\begin{array}{l}\text { Interpretation of Landsat } 8 \text { image (2015) from USGS } \\
\text { website }\end{array}$ \\
\hline 2 & $\begin{array}{l}\text { Slope, Aspect and } \\
\text { Elevation }\end{array}$ & Raster & Interpretation of ASTER GDEM image (2015) \\
\hline 3 & Soil texture & $\begin{array}{l}\text { Vector, Shape } \\
\text { file }\end{array}$ & Minister of Water and Energy, Addis Ababa \\
\hline 4 & Geology type water & $\begin{array}{l}\text { Vector, Shape } \\
\text { file }\end{array}$ & Interpretation of ASTER GDEM image (2015) \\
\hline 5 & $\begin{array}{l}\text { Surface } \\
\text { (river/streams) }\end{array}$ & $\begin{array}{l}\text { Vector, Shape } \\
\text { file }\end{array}$ & Amhara Water Well Drilling Enterprise office, Bahir Dar \\
\hline 6 & Groundwater wells & $\begin{array}{l}\text { Vector, Shape } \\
\text { file }\end{array}$ & Amhara Water Well Drilling Enterprise office, Bahir Dar \\
\hline 7 & Road network & $\begin{array}{l}\text { Vector, Shape } \\
\text { file }\end{array}$ & $\begin{array}{l}\text { Interpretation the study area of Topographical map from } \\
\text { (EMA), Addis Ababa }\end{array}$ \\
\hline 9 & Settlements & $\begin{array}{l}\text { Vector, Shape } \\
\text { file }\end{array}$ & Interpretation the study area of Google earth map (2015) \\
\hline
\end{tabular}




\subsection{Methodology}

In this study, to generate a suitability map of wastewater treatment plant site is a combination of final constraint map and weighted factor map with in a GIS environment.

As for the final weighted factor map is a weighted linear combination of factor maps, an equation (1) as following:

$\mathrm{S}=\Sigma$ wi xi where, $\boldsymbol{S}=$ suitability, $\boldsymbol{w i}=$ weight of factor i and $\boldsymbol{x i}=$ factor map i.

As for the Boolean overlay operations, the equation for generating the final constraint map is shown as equation (2) below:

$\mathrm{C}=\Pi$ cj $\quad$ where, $\boldsymbol{c j}=$ constraint map j, $\boldsymbol{\Pi}=$ product

The suitability map is derived by multiplying the overall weighted factor map and overall constraint map, as follows equation (3).

$$
\mathrm{S}=\sum_{\mathrm{i}=1}^{\mathbf{N}} \text { wixi } \mathrm{x} \text { Пcj }
$$

Where, $\boldsymbol{S}$ is the suitability to the wastewater treatment plant location, $\boldsymbol{x i}$ is the factor map $\boldsymbol{i}$, wi is the weights assigned to each factor and $\boldsymbol{N}$ is the number of factors. After the final factor map and final constraint map can produce the final suitability map by overlay final constraint map with final weighted factor map.

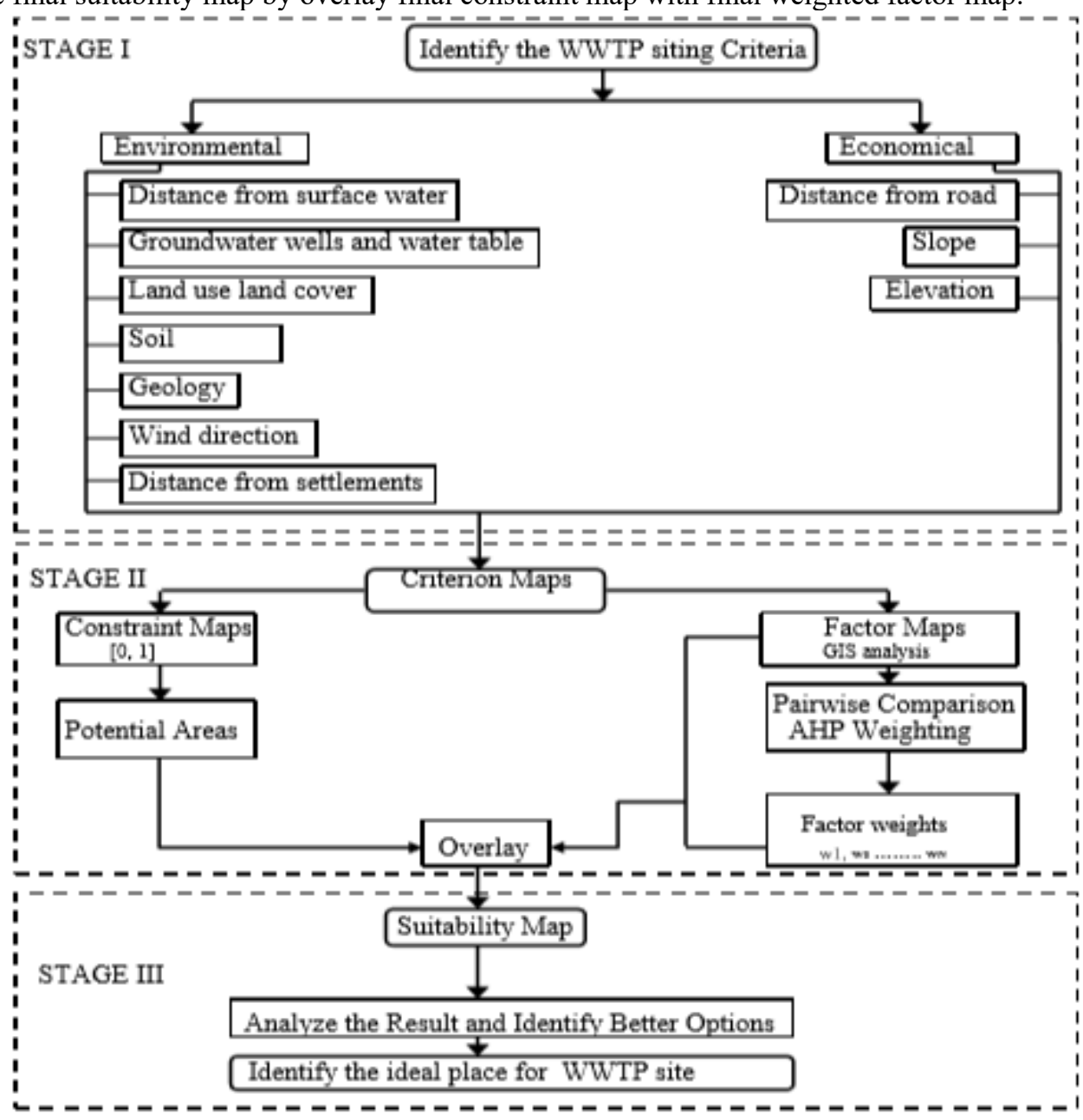

Fig 2: Flow chart of the Methodology

\subsection{Description and Analysis of Each Data Factors}

\subsubsection{Land Use - Land Cover Factor}

The land use is considered an environmental factor in construction of wastewater treatment plant site. In the present study land use/land cover was analyzed from Landsat 8 image data for the wastewater treatment plant site selection. In the study area, there are six major land uses such as water body, built-up area and airport, agricultural land area, cultivated land, vegetation and barren/grass land areas. By reviewing different literature, it was advisable to select land, it was occupied by bare and grass lands suitable for wastewater treatment plant site. 


\subsubsection{Distance from Settlements Factor}

Wastewater treatment plants should not be located very close to urban residential and rural areas in order to protect the public from the nuisance and health impacts due to the potential hazards from wastewater. In the same time, it should not be located too far to avoid extra cost of wastewater treatment plant construction and maintenance. According to international literatures [2] [7] [12], wastewater site at a distance less than 1000m from urban area are not allowed. In this study, the safe distances from settlements are determined as $6000 \mathrm{~m}$ for urban centers and $2000 \mathrm{~m}$ for rural villages. Like other criteria, settlement areas were classified according to their suitability for wastewater treatment plant site.

\subsubsection{Distance from Groundwater Wells Factor}

A total of 21 points ground water wells, data were obtained from Amhara Water Well Drilling Enterprise Office (AWWDEO), Bahir Dar. Proximity of wastewater treatment plant site to a groundwater well is one of the most important environmental criteria in the wastewater treatment plant suitability site selection. It helps in protecting groundwater wells from contamination of wastewater. There is no specific criterion of what is the best distance to locate the wastewater treatment plant site away from groundwater wells. According to that the wastewater treatment plant sites should be located $500 \mathrm{~m}$ far from the groundwater wells [13].

\subsubsection{Distance from Surface Water Factor}

Generally, wastewater discharge areas must not be sited near rivers, lakes, streams, ponds or swamps. Amhara National Regional State has established the Regional Hygiene and Environmental Executive Committee which has issued regional environmental sanitation regulations (No.16/2000); it clearly states that wastewater should not be discharge to any water surface like river, stream, lake etc. In the study area, Abbay River and Lake Tana are the main surface water. Researchers have suggested a distance up to 500m away from surface water [9].

\subsubsection{Depth to Water Table Factor}

The water table data were obtained from existing wells in the study area provided by the Amhara Water Well Drilling Enterprise office, Bahir Dar. The depth to water table was determined using the inverse distance weighting (IDW) interpolation of the water level data, to distinguish deep water table areas from shallow water tables areas. The depth of groundwater table is a significant parameter in determining the contamination risk of groundwater in order to limit potential contamination. The precipitation, site topography and soil type affects the rate of infiltration into the water table [14]. In the study area, Most of the available water table data depths less than $5 \mathrm{~m}$.

\subsubsection{Soil Types Factor}

There were six type of soils texture in the study area based on FAO (2000) method such as eutric vertisols, chromic luvisols, haplic luvisols, eutric regosols, lithic Leptosols and eutric leposols. Soil should be of sufficiently low permeability to significantly slow the passage of leachate from the site. Soil characteristics of textures were considered. Clay textured soil was most preferred for wastewater treatment plant as it is impermeable to leachate. Thus, sites in clay-rich environments are most preferable. The higher the permeability of the textured unit, the lower is the site suitability for wastewater treatment plant practices and the higher is its vulnerability. In the present study, soil texture was classified into four zones according to the texture unit of permeability characteristics.

\subsubsection{Geology Types Factor}

The geological map of the study area was extracted from geology map using ArcGIS software and the vector format of the soil data converted to raster format. On incorporating the nature of rocks, degree of weathering, permeability and extent of fractures the town area was reclassified into four wastewater treatments plant suitability classes area consisting of Alluvium, Tarmaber basalts, Basalts related to volcanic center and Ashangi basalts. Alluvium deposit has high potential for water adsorption and is a very low suitable for wastewater treatment plant site. Tarmaber basalts are high permeability are thus the low suitable lithological units for wastewater treatment plant site. Basalts related to volcanic center are low permeability and has limited water adsorption potential. Ashangi basalts are a very low permeability and are thus the high suitable lithologic units for wastewater treatment plant site.

\subsubsection{Wind Direction Factor}

The wind direction is not known to be subject to any legal restrictions. But based on the premise that wastewater treatment plant site should not be in the direction of the wind. It is also an established fact that the direction of winds vary with altitude, slope and terrain roughness. To evaluate the wind direction of the study area, an aspect map was prepared using a digital elevation model with a 30x30m resolution. The site wind direction frequency of the study area was taking into consideration. The wind frequency percentages data were obtained from the National Meteorological Agency of Ethiopia (2014), the least frequently encountered winds in Bahir Dar town were the S and SW winds. But records of Meteorological Agency; indicate that the $\mathrm{N}$ and NE wind is dominant in the study area. Hence, the locations of $\mathrm{N}$ and $\mathrm{NE}$ areas are unsuitable, because they are more exposed to the wind and also the flat areas unsuitable, because these areas are susceptible to wind from all directions. 


\subsubsection{Distance from Road Network Factor}

This criterion is concerned with the distance from the road network. The road network in the town consists of major roads and others. The road network layer of the study area was digitized from the study area of Topographical map. There is no specific rule of what should be the best distance to place the wastewater treatment plant site. Most studies suggested that the wastewater treatment plant site should be located within a $500 \mathrm{~m}$ buffer from the roads [13]. However, planners may prefer to give an aesthetic concern when deciding a location of wastewater treatment plant site. Also, the wastewater treatment plant site should not be placed too far from the existed road networks, to avoid the expensive cost of wastewater treatment plant construction and maintenance; however, the presence of the wastewater treatment plant close to the major roads affects the public health.

\subsubsection{Slope Factor}

The slope was generated from the ASTER GDEM data. Slope refers to the measures of the rate of change of elevation at a surface location and normally expressed in percent or degree slope. Construction of wastewater treatment plant in too steep slope sites will increase the cost of excavation and embankment. The appropriate slope for constructing wastewater treatment plant is about $8^{0}-12^{0}$ because too steep of a slope would make it difficult to construct and maintain, while too flat of a slope would affect the runoff drainage [10].

\subsubsection{Relief Factor}

Relief was generated from the ASTER GDEM data. The elevation of the study area generally ranges between $1705 \mathrm{~m}$ and $2017 \mathrm{~m}$. Elevation is a basic parameter for the construction of wastewater treatment plant site. Areas with too high elevation are not suitable wastewater treatment plant site. Because of it is difficult to permit gravity flow. The best places for wastewater treatment plant should be located at a low elevation in order to permit gravity flow.

Table 2: Summary of main criteria, sub criteria, class/buffer zone, ranking and their level of suitability

\begin{tabular}{|c|c|c|c|c|}
\hline Main criteria & Sub Criteria & Class/ buffer zone & Ranking & Level of suitability \\
\hline \multirow{34}{*}{ Environmental } & \multirow{4}{*}{$\begin{array}{l}\text { Land use- land } \\
\text { cover }\end{array}$} & Water bodies, Airport, Built up area & 1 & Unsuitable \\
\hline & & Agriculture \& cultivated land & 2 & Very low suitable \\
\hline & & Vegetation & 4 & Moderate suitable \\
\hline & & Barren/grass land & 5 & High suitable \\
\hline & \multirow{5}{*}{$\begin{array}{l}\text { Distance from } \\
\text { river/streams }\end{array}$} & $0-500 \mathrm{~m}$ & 1 & Unsuitable \\
\hline & & $500-1000 \mathrm{~m}$ & 2 & Very low suitable \\
\hline & & $1000-1500 \mathrm{~m}$ & 3 & low suitable \\
\hline & & $1500-2000 \mathrm{~m}$ & 4 & Moderate suitable \\
\hline & & $>2000 \mathrm{~m}$ & 5 & High suitable \\
\hline & \multirow{5}{*}{$\begin{array}{l}\text { Distance from } \\
\text { Lake Tana }\end{array}$} & $0-500 \mathrm{~m}$ & 1 & Unsuitable \\
\hline & & $500-1000 \mathrm{~m}$ & 2 & Very low suitable \\
\hline & & $1000-1500 \mathrm{~m}$ & 3 & low suitable \\
\hline & & $1500-2000 \mathrm{~m}$ & 4 & Moderate suitable \\
\hline & & $>2000 \mathrm{~m}$ & 5 & High suitable \\
\hline & \multirow{5}{*}{$\begin{array}{l}\text { Distance from } \\
\text { Groundwater } \\
\text { well }\end{array}$} & $0-500 \mathrm{~m}$ & 1 & Unsuitable \\
\hline & & $500-1000 \mathrm{~m}$ & 2 & Very low suitable \\
\hline & & $1000-1500 \mathrm{~m}$ & 3 & low suitable \\
\hline & & $1500-2000 \mathrm{~m}$ & 4 & Moderate suitable \\
\hline & & $>2000 \mathrm{~m}$ & 5 & High suitable \\
\hline & \multirow{5}{*}{$\begin{array}{l}\text { Groundwater } \\
\text { tables }\end{array}$} & $0-5 \mathrm{~m}$ & 1 & Unsuitable \\
\hline & & $5-8 \mathrm{~m}$ & 2 & Very low suitable \\
\hline & & $8-12 \mathrm{~m}$ & 3 & low suitable \\
\hline & & $12-15 \mathrm{~m}$ & 4 & Moderate suitable \\
\hline & & $>15 \mathrm{~m}$ & 5 & High suitable \\
\hline & \multirow{5}{*}{$\begin{array}{l}\text { Distance from } \\
\text { Urban areas }\end{array}$} & $0-1000 \mathrm{~m} \&>6000 \mathrm{~m}$ & 1 & Unsuitable \\
\hline & & $1000-2000 \mathrm{~m}$ & 2 & Very low suitable \\
\hline & & $2000-3000 \mathrm{~m}$ & 3 & low suitable \\
\hline & & $3000-4000 \mathrm{~m}$ & 4 & Moderate suitable \\
\hline & & $4000-6000 \mathrm{~m}$ & 5 & High suitable \\
\hline & \multirow{5}{*}{$\begin{array}{l}\text { Distance from } \\
\text { rural areas }\end{array}$} & $0-500 \mathrm{~m}$ & 1 & Unsuitable \\
\hline & & $500-1000 \mathrm{~m}$ & 2 & Very low suitable \\
\hline & & $1000-1500 \mathrm{~m}$ & 3 & low suitable \\
\hline & & $1500-2000 \mathrm{~m}$ & 4 & Moderate suitable \\
\hline & & $>2000 \mathrm{~m}$ & 5 & High suitable \\
\hline
\end{tabular}




\begin{tabular}{|c|c|c|c|c|}
\hline & \multirow[t]{4}{*}{ Aspect } & N,NE, Flat & 2 & Very low suitable \\
\hline & & $\mathrm{NW}, \mathrm{E}$ & 3 & low suitable \\
\hline & & $\mathrm{W}, \mathrm{SE}$ & 4 & Moderate suitable \\
\hline & & S,SW & 5 & High suitable \\
\hline & \multirow[t]{4}{*}{ Geology type } & Alluvium & 2 & Very low suitable \\
\hline & & Tarmaber Basalt & 3 & low suitable \\
\hline & & Volcanic & 4 & Moderate suitable \\
\hline & & Ashangi Basalt & 5 & High suitable \\
\hline & \multirow[t]{4}{*}{ Soil type } & Lithic \& Euric leptosols & 2 & Very low suitable \\
\hline & & Euric Regosols & 3 & low suitable \\
\hline & & Chromic \& Haplic luvisols & 4 & Moderate suitable \\
\hline & & Eutric vertisols & 5 & High suitable \\
\hline \multirow{14}{*}{ Economical } & \multirow{5}{*}{$\begin{array}{l}\text { Distance from } \\
\text { Road networks }\end{array}$} & $0-500 \mathrm{~m} \&>5000 \mathrm{~m}$ & 1 & Unsuitable \\
\hline & & $500-1000 \mathrm{~m}$ & 2 & Very low suitable \\
\hline & & $1000-1500 \mathrm{~m}$ & 3 & low suitable \\
\hline & & $1500-3000 \mathrm{~m}$ & 4 & Moderate suitable \\
\hline & & $3000-5000 \mathrm{~m}$ & 5 & High suitable \\
\hline & \multirow[t]{4}{*}{ Slope } & $0^{0}-10^{0}$ & 5 & High suitable \\
\hline & & $10^{0}-15^{0}$ & 4 & Moderate suitable \\
\hline & & $15^{0}-20^{0}$ & 3 & low suitable \\
\hline & & $>20^{0}$ & 1 & Unsuitable \\
\hline & \multirow[t]{5}{*}{ Relief } & $1705-1750 \mathrm{~m}$ & 2 & Very low suitable \\
\hline & & $1750-1850 \mathrm{~m}$ & 5 & High suitable \\
\hline & & $1850-1900 \mathrm{~m}$ & 4 & Moderate suitable \\
\hline & & $1900-1975 \mathrm{~m}$ & 3 & low suitable \\
\hline & & $1975-2017 \mathrm{~m}$ & 1 & Unsuitable \\
\hline
\end{tabular}

Analytical Hierarchical Process (AHP): AHP was used to obtain the mapping weight or importance of each individual factor for selection of waste water treatment plant site. The treatment plant site selection factors do not have the same role and weight in the modeling of the final waste treatment plant site. In order to designate the importance of each parameter, we weighted them using a pair wise comparison method which is one of the components of AHP. According to the AHP calculations, the weight of the environmental criteria was 0.75 , and the weight of the economic criteria was 0.25 , suggesting that environmental criteria were more influential than to economical criteria for wastewater treatment plant site selection. The Slope criterion was assigned the highest weight value in the economic criteria because the finding of the study focuses on to economical suitability, as obstacles related to slope can be overcome with cost of excavation, fill and the maintenances. And also the land use land cover criterion was assigned the highest weight value in the environmental criteria because the finding of the study focuses on to environmental suitability, as it is considering future urban development and to protect human being from environmental hazards for the area. All of considered main and their sub criteria weight were summarized in (table 3 ).

Table 3: The weights of main and sub criteria

\begin{tabular}{|c|c|c|c|c|c|c|}
\hline Objective & Main criteria & eight & sub criteria & weight & $\mathrm{CR}$ & EWeight \\
\hline \multirow{13}{*}{$\begin{array}{l}\text { Suitability of } \\
\text { WWTP site }\end{array}$} & \multirow{10}{*}{ Environmental } & \multirow{10}{*}{0.75} & Land use land cover & 0.193 & \multirow{10}{*}{0.03} & 0.14 \\
\hline & & & River/streams in (m) & 0.138 & & 0.10 \\
\hline & & & Lake Tana in (m) & 0.138 & & 0.10 \\
\hline & & & Groundwater wells in (m) & 0.138 & & 0.10 \\
\hline & & & Groundwater tables in (m) & 0.138 & & 0.10 \\
\hline & & & Urban residential area in $(\mathrm{m})$ & 0.091 & & 0.07 \\
\hline & & & Rural settlement area in (m) & 0.073 & & 0.05 \\
\hline & & & Soil texture & 0.035 & & 0.03 \\
\hline & & & Geology type & 0.035 & & 0.03 \\
\hline & & & Wind direction & 0.021 & & 0.02 \\
\hline & \multirow{3}{*}{ Economical } & \multirow{3}{*}{0.25} & Slope in (degree) & 0.582 & \multirow{3}{*}{0.00} & 0.15 \\
\hline & & & Elevation in $(\mathrm{m})$ & 0.309 & & 0.08 \\
\hline & & & Road networks in (m) & 0.109 & & 0.03 \\
\hline
\end{tabular}

(Note: $\mathrm{CR}$ is consistency ratio) 


\section{RESULTS AND DISCUSSION}

\subsection{Overlay Analysis and Identifying Suitable Areas}

To determine the suitable areas for wastewater treatment plant sites, there are thirteen factors were considered. Each factors thematic map was prepared using ArcGIS Spatial Analyst tools, and prepared maps were converted into raster format. The overlay analyses of the final constraint map with final weighted factor map were integrated and produced the final suitable wastewater treatment plant site map was prepared using ArcGIS software by the following principle:

Suitability Map $=\Sigma[($ Criteria map * weight $) *$ constraint map $]$

Suitability index $=([$ surface water map] $* 0.1+$ [groundwater wells map] $* 0.1+$ [ground water table map $]^{*} 0.1+[\text { land use map }]^{*} 0.14+[\text { slope map }]^{*} 0.15+[\text { elevation map }]^{*} 0.08+[\text { urban area map }]^{*} 0.07+[$ rural area map $\left.]^{*} 0.05+[\text { soil map }]^{*} 0.03+[\text { geology map }]^{*} 0.03+[\text { road map }]^{*} 0.03+[\text { wind direction map }]^{*} 0.02\right) *$ constraint map of (surface water * slope * elevation * urban area* road * rural area * land use * groundwater wells * groundwater table).

The results from the integration of weighted factor map and constraint map in the ArcGIS software reveals four suitability indices for the municipal wastewater treatment plant site of Bahir Dar town. These are unsuitable (restricted), low suitable, moderately suitable and highly suitable site for waste water treatment plant.

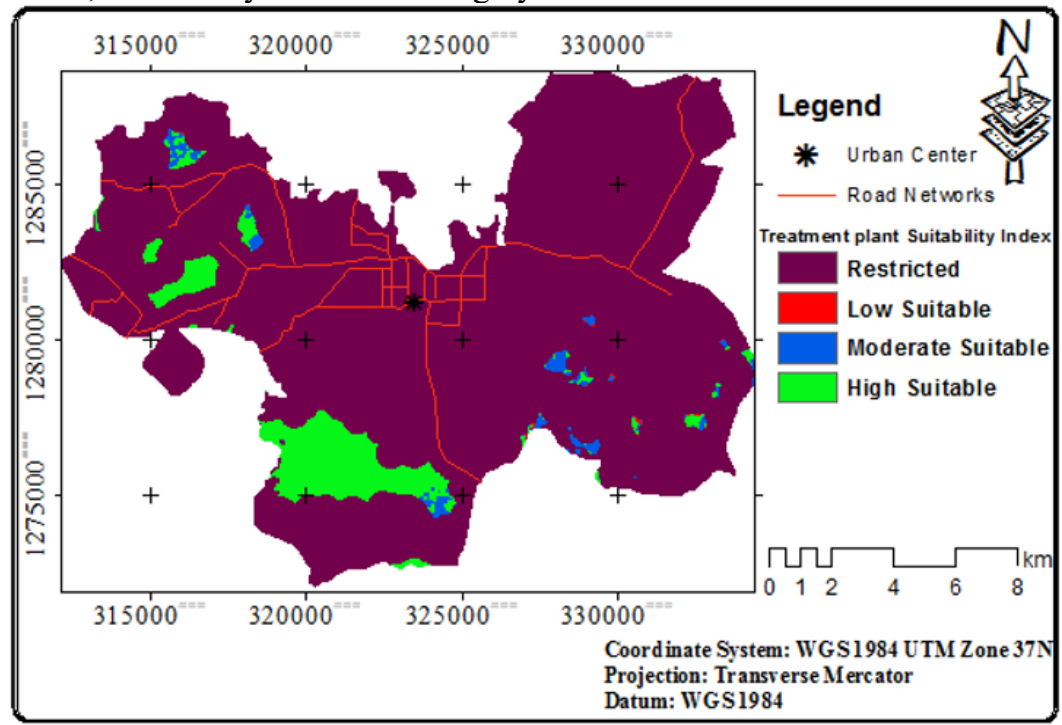

Fig 3: Wastewater treatment plant sites suitability Map of Bahir Dar town

The area coverage of each suitability index of the sites was calculated in ArcGIS environment showed that $195.22 \mathrm{~km}^{2}(91.48 \%)$ of the study area is unsuitable (restricted) for wastewater treatment plant site as the areas are environmentally unfavorable and economically impracticable to be proposed as wastewater treatment plant site. This unsuitable (restricted) area include close to surface water (river, streams, lake) ( $<500 \mathrm{~m}$ buffer zone), groundwater wells $(<500 \mathrm{~m}$ buffer zone), groundwater table $(<5 \mathrm{~m}$ depth), settlements $(<500 \mathrm{~m}$ buffer zone for rural, $<1000 \mathrm{~m}$ buffer zone for urban area), areas with steep slope $(>200)$, areas with higher relief $(>1975 \mathrm{~m})$, areas with built-up area, airport, water bodies and areas with close to road networks and far from road networks $(<500 \mathrm{~m} \&>5000 \mathrm{~m}$ buffer zone $)$, respectively. The main advantage of these areas restriction was to minimize their negative effects of on environment and public health as well as to minimize the cost of construction and maintenance of the wastewater treatment plant site. However, $1.30 \mathrm{~km}^{2}(0.61 \%)$ of the area was low suitable for wastewater treatment plant site and the area of $3.91 \mathrm{~km}^{2}(1.83 \%)$ moderately suitable. Out of the remaining area, $12.98 \mathrm{~km}^{2}(6.08 \%)$ of the area was high suitable, these areas are preferable for wastewater treatment plant, because of their minimum effect on environment, public health and cost effective than other parts of the study area.

Table 4: Statistical analysis for the wastewater treatment plant site suitability

\begin{tabular}{|c|r|r|}
\hline \multicolumn{1}{|c|}{ Suitability index } & Area $\left.\mathbf{( k m}^{\mathbf{2}}\right)$ & Area (\%) \\
\hline Unsuitable (Restricted) & 195.22 & 91.48 \\
\hline Low Suitable & 1.30 & 0.61 \\
\hline Moderate Suitable & 3.91 & 1.83 \\
\hline High Suitable & 12.98 & 6.08 \\
\hline Total & $\mathbf{2 1 3 . 4 1}$ & $\mathbf{1 0 0}$ \\
\hline
\end{tabular}


Most of the highly suitable wastewater treatment plant sites are located in the southern and western part of the study area in (fig 3). The south eastern part of the town having high altitude and close to rural settlement was excluded from the selection of high suitable wastewater treatment plant sites.

\section{CONCULUSION}

This study shows how to use GIS-based multi-criteria analysis (MCA) to select the optimal site for wastewater treatment plant. The suitable site selection of wastewater treatment plant site in Bahir Dar town, the weight of main and sub criteria were evaluated according to their importance. Each criteria map was mapped by using GIS spatial analysis tools. The overlay analysis of the given weighted factor maps and constraint maps were integrated and produced the final suitable wastewater treatment plant site map was prepared. The area was classified into four groups of high, moderate, low and unsuitable, which covered $6.08 \%, 1.83 \%, 0.61 \%$, and $91.48 \%$ of the study area, respectively. The outcome showed that the area of proposed in the southern part of the town is the optimal suitable wastewater treatment plant site will minimize public concerns over health and environmental impacts and will be economical suitable.

\section{References}

[1] Abdullahi and Usman (2013). Location Optimization of wastewater Treatment Plants Using GIS: A Case Study in Upper Mahaweli Catchment, Sri Lanka.

[2] Ahmad A., Bayan A. and Akihiko K. (2011). GIS-Based Weighted Linear Combination Analysis and Remote Sensing Techniques to Select Optimum Solid Waste Disposal Sites within Mafraq City, Jordan. . Journal of Geographic Information System; 19(3): 267-278.

[3] Basak Sener (2004). Landfill site selection by using geographic information systems. Department of Geological Engineering, 114 p.

[4] Benujah B. and G.Devib (2013). Site Suitability Evaluation For Sewage Treatment Plant In Nagercoil Municipality, Tamil Nadu Using Remote Sensing Techniques, Regional Centre of Anna University Tirunelveli, India.

[5] Fesseha H. (2012). Liquid waste management. The case of Bahir Dar Town, Bahir Dar University, Department of Geography. Ethiop. J. Health Dev, 26(1):49-53.

[6] Habitat U. (2008). The Central Role of Wastewater Management in Sustainable Development. Available from: www.unhabitat.org.

[7] IIsalou A. A., and Zamani V. (2012). Landfill site selection using integrated fuzzy logic and analytic network process (F-ANP). Environ Earth Sci. DOI 10.1007/s12665-012-1865-y.

[8] Kao J. J. and Lin H.Y. (2005). Grid-based heuristic method for multifactor landfill siting. Journal of Computing in Civil Engineering; 19(4): 369-376.

[9] Kontos T. D., Komilis. D.P. and Halvadakis C. P. (2005). MSW landfills with a spatial multiple criteria analysis methodology, Waste Manag; 25:818-832.

[10] Lin H.Y. and Kao J.J. (1999). Enhanced spatial model for landfill siting analysis, Journal of Environmental Engineering; 125 (9): 845-851.

[11] Malczewski J. (1999). Propogation of errors in multicriteria location analysis: a case study in: fandel G., Gal T. (eds.) Multiple Criteria Decision Making, Springer- Verlag Berlin; 154155.

[12] Sehnaz S., Erhan S. and Bilgehan (2011). Selection of Landfill Site using GIS and Multicriteria Decision Analysis for Beysehir Lake Catchment area (Konya, Turkey). Journal of Engineering Science and Design; $1(3): 134-144$.

[13] Shahmoradi B.and Isalou AA, (2013). Site selection for wastewater treatment plant using Integrated fuzzy logic and multicriteria decision model: A case study in Kahak, Iran. Adv Environ Health Res; 1(1): 51-61.

[14] Udomporn, W. Wanpen, C.Punya, M. William and Rungruang (2009). Landfill Site Characterization Kham Bon Village, Muang District, Khon Kaen Province, NE Thailand, International Journal of Environment and Waste Management; 4 (2-3): 299-321. 